\title{
Principles of Environmental Ethics in Indonesian Newspaper Short Stories: An Ecocriticism Study
}

\author{
Pradita Widyaningtyas* \\ Indonesian Language and Literature Education of Graduate School \\ Universitas Negeri Yogyakarta \\ Yogyakarta, Indonesia \\ Praditawidyaningtyas.2018@student.uny.ac.id
}

\author{
Else Liliani \\ Faculty of Language and Art \\ Universitas Negeri Yogyakarta \\ Yogyakarta, Indonesia \\ else_1@uny.ac.id
}

\begin{abstract}
This study aims to describe the forms of environmental problems and determine the principles of environmental ethics contained in four online short stories published in Jawa Pos in 2017. The data of the research are in the form of words and paragraphs containing the environmental problems and ethics principles. Data collection is carried out by recording and classification techniques; while data analyzing is done by interpretation and description techniques. Applying the theory of ecocriticism, the study found that the forms of environmental problems reflected in the stories are related to forests, settlements, pollution, and animals, whereas, the principles of environmental ethics are respecting, caring, and living in harmony with nature.
\end{abstract}

Keywords-Ecocriticism, Short Stories, Jawa Pos online Newspaper

\section{INTRODUCTION}

The environmental destruction often occurs in Indonesia. Some of them include illegal logging, forest fires, coral reefs ravage, and some other environmental hazards resulted from irresponsible acts of Indonesian people. Responding to the ongoing destruction, environmentalists do not only take to the streets to remind people about the critical condition of nature but also do some voluntary works such as planting trees and restricting the use of a plastic bag. Besides, they ask people in the community to pay more attention to their surroundings.

Literary works also take part in the process of informing readers about environmental problems. It shows the concern both implicitly and explicitly within the text(Juliasih, 2015). Short stories in newspapers are a place for local or regional writers to express their anxiety related to environmental destruction. Newspaper, other than as a medium of information, is used as a forum for expressing opinions, obtaining entertainment, and publishing literary works. "Newspaper Literature" is a form of a masterpiece whose literary quality is still being debated but its popularity and acceptance are profound for readers in Indonesia (Bandel, 2006).

In Indonesia, there are various types of newspapers such as Kedaulatan Rakyat, Kompas, Tempo, Suara Merdeka, Republika, Media Indonesia, Jawa Pos, and some others. Jawa Pos is one of the newspapers which has a column for literary writing. Some writers send their short stories and poetry to be published in the section. Writers who contribute to it select various themes for their writing. The environment is one of the subjects coloring the stories published in the Jawa Post online newspaper. Some authors develop their writing based on their observation and experience living in inconvenient surroundings.

Literary research can generally be done on novels, short stories, poetry, drama, oral literature and even on films and songs. Wiyatmi (2015) explained that studies on literary works using the eco-criticism focus on nature, environment, and other aesthetic aspects of a literary work. As many poets and authors tell their stories using diction such as mountains, trees, and seas, and also explore the overuse of nature and injustice behavior of humans against nature, their works are potential to be investigated applying eco-criticism.

Garrard (2004) in his book Ecocriticism, explained that eco-criticism is a way of exploring the relationship between humans and the environment in all fields of cultural production. Garrard tracked the development of ecocriticism movement and summarized that the most obvious critical concepts highlighted by eco-critics are pollution, wilderness, doomsday, shelter, animals, and earth. Before Garrard, Glofelty (1996) has also highlighted the same critical concern on the literary study and the problem of ecology. He emphasized that ecocriticism focus on investigating the relationship between literature and the physical environment.

Ecology literature is a way of looking at environmental issues from a literary perspective and how to understand literature from an environmental standpoint. In its function as an attitude of representations, views, and responses medium of the community to the surrounding environment, literature tends to also express ideas about values and environmental wisdom. This is very reasonable considering that literature grows and develops from a community and its environment (Endraswara, 2016).

Ecocriticism (eco-criticism) applies the concept of ecology into literature. the earth (nature) is the focus of its studies (Sudikan, 2016). It appeared in 1980 when a paper on literary studies investigated nature and environmental problems. In the early 1990s, ecocriticism was widely used as an approach in literary research, especially in America. It has also inspired the modern environmental movements.

In protecting the environment, ethics and norms are also needed. Ethics can be seen as good living habits passed down over generations. Ethics contains rules about how humans should behave and live a good life. It also provides commands about the good and bad behavior that are necessary to main or to avoid. Today it can be seen that the behavior of humans is the primary cause of damage and pollution of the natural environment. Therefore, 
environmental ethics is needed as a moral policy of humans in dealing with the environment (Najmuddin, 2005)

Environmental ethics are based on the theory of biocentrism and ecocentrism. They are the environmental theories which emphasize on anthropocentric understanding or an understanding that humans are the center of the universe system. In this perspective, humans and their interests are considered important, and nature is considered to have no value so it has the right to be exploited. Biocentrism is the view that all living things have value and are valuable in themselves. Nature needs to be treated morally, regardless of their degree of usefulness for humans (Keraf, 2010). Furthermore, ecocentrism is ethics that focuses on the entire ecological community, both living and non-living. Ecologically, living things and other abiotic objects are related to one another. Thus, environmental issues cannot be placed in a restricted discipline because they involve greater moral, ethical, and humanitarian responsibilities (Dewi, 2015). Everyone bears the responsibility of loving and caring for other living creatures.

Environmental ethics are needed to guide humans maintaining the balance of the universe. Environmental ethics (ecological ethic) is an approach that sees the interdependence between humans and nature and stresses the importance of understanding and supporting the life of each other. The principle of ecological ethics is that all forms of life have innate values and therefore have the right to claim respect for self-esteem, the right to live and the right to develop. Besides, ethics is the science of what is good and what is bad and about values and moral rights and obligations (morals). There are several categories of principles on environmental ethics namely respect for nature, affection for nature, and life in harmony with nature bearings (Keraf, 2010).

Based on a brief explanation above, this research focuses on short stories in Jawa Pos newspaper published in 2017. The short stories in the newspaper are very appealing to study because they are written by local authors. This research tries to explore the form of ecological criticism and also the environmental ethics presented in the selected short stories.

\section{METHODOLOGY}

This is a content analysis of qualitative research with an ecocritical approach. The data of this study are sentences and paragraphs that focus on the representation of environmental problem and ethics discourse in four selected short stories published in Jawa post newspaper in 2017. The sources of data are S. Prasetyo Utomo "Pertunjukan Hari Ketujuh", January 22, 2017; Toni Lesmana "Nini Rumi", 7 May 2017; Jemmy Piran "Dalam Lingkaran Laut", September 3, 2017; Dahlia Rasyid "Ular Sawit", October $22,2017$.

The analysis of the data was started with the process or reading and downloading four selected short stories uploaded in http://lakonhidup.blogspot.com//. Then, the short stories with environmental themes were marked for further reading. The reading results were then grouped based on (1) the form of environmental problems that occurred in the short story, (2) the form of environmental ethics principles contained in the short story.

\section{RESEARCH RESULTS AND DISCUSSION}

\section{A. Environmental Problems}

In the process of critical reading on the selected short, four environmental problems were found; (1) forests, (2) settlements, (3) pollution, (4), animals. The data were as follows:

\section{Forests}

From the four newspaper short stories, three data are describing environmental problems in the forest. The three data are obtained from Pertunjukkan Hari Ketujuh and Nini Rumi.

The author of Pertunjukkan Hari Ketujuh reveals two environmental problems in the forest. They are water scarcity and land damage. These environmental damages are due to industrial development and deforestation which overexploiting the forests. The following is the data on the environmental problems presented in the short story.

1) "Kodrat ingin mengatakan semuanya kepada presiden bahwa pabrik semen yang didirikan di lembah Gunung Bokong merusak alam di daerah kapur itu, mematikan mata air, dan menghancurkan bumi tempat mereka bertani. Ia, mewakili kehendak warga, menyampaikan pesan agar pabrik semen itu segera ditutup. “ (Utomo, PHK).

2) Truk tergoncang-goncang melewati jalanan rusak desa lembah gunung bokong yang diteduhi hutan jati. [...]. berkali-kali ia berpapasan dengan truk tronton, membawa alat-alat berat yang diangkut ke pabrik semen. Truk-truk perkasa itu dikemudikan sopir yang tak peduli dengan siapapun di atas tanah kapur. Truk-truk melintas selalu menyisakan kepulan debu keputihan." (Utomo,PHK).

In Pertunjukkan Hari Ketujuh (PHK) by S. Prasetyo Utomo, data (1) shows that the establishment of a cement factory has damaged the spring and the land for agriculture in the valley of Mount Bokong. Meanwhile, data (2) explains that machinery construction has also spoiled the land of Mount Bokong. Moreover, the chalky soil of Mount Bokong has caused dust puffs that contribute to air pollution. Nowadays, many development activities do not pay attention to their impact on the environment. Many parties try to exploit natural resources to make maximum profit. Land, mountains and forests keep on being utilized to achieve the target for economic growth (Hunga \& Chandraningrum, 2016). Humans do not preserve nature and ignore the sustainability of the environment.

Environmental issues that occurred in forests are also found in Nini Rumi by Tono Lesmana.

3) "Sekarang ini sudah tidak ada lagi yang bernyanyi dari rumpun ke rumpun, dari dahan ke daun. Yang ada hanya suara bedil dan gergaji yang setiap saat mengiris hutan. Lagi pula, tua dan nenek-nenek itu di kampung, tapi di sini, di kerajaan kami ini tak ada yang rapuh karena umur," salah seorang 


\section{menjawab lagi sambil tersenyum." (Lesmana,NR).}

Nini Rumi (NR) tells about an old woman named Nini Rumi. She is very fond of singing, intonated wawangsalan, paparikan, or satire when she is all by herself. Data (3) elaborates that the sounds heard in the forest is no longer the voices of birds or the humming of other animals. It is now changing into the sound of hunting guns and saw machines. Illegal logging and illegal hunting have resulted in the extinction of the songs of nature. These also influence nature's sustainability. Christinawati (2018) explains that another impact of forest and land exploitation is a drastic decline in the quality of natural resources, such as the loss of some species and the declining quality of nature.

From the two short stories, it could be concluded that the forest has suffered great loss and damage. They also explain that the forest has changed after the establishment of a cement factory. Furthermore, the sound of hunting guns the cutting of the trees becomes the melody of the forest. These illegal activities have caused forest destruction. The forest damaged often occurs due to the perspective of human anthropocentrism. Even if humans have a caring attitude towards nature, it is only done to ensure the needs of human life, not because of the consideration that nature has a value that deserves to be protected (Keraf, 2010).

\section{Settlement}

Two data are focusing on the environmental problems occurred in settlements. They are presented in Ular Sawit (US) by Dahlia Rasyid. The story describes an area where the forest is transformed into an oil-palm plantation. Conflicts occurred among local people or tribal children, oil palm workers, and a tumenggung or a regent. The data about the environmental destruction from the story could be seen in the following explanation.

4) "Sejak hutan dibakar habis lalu muncul bibitbibit sawit di seluruh lahan, mereka sudah tak tahu lagi harus ke mana. Mengambil wilayah jelajah di pedalaman hutan yang masih lebat sudah tak mungkin." (Rasyid,US).

From the data (4), the environmental problem occurred is the conversion of forest into oil palm plantation. Tribal children as a local community are depressed because of this. Their lives would be hard because the foods that are supplied will disappear when the forest turns into oil palm plantation. Keraf (2010) states that the destruction of forests will lead to the extinction of various flora and fauna, biodiversity and loss of various sources of raw materials for medicines.

\section{Pollution}

The next environmental problem is soil pollution. The data is found in Ular Sawit (US). It can be identified as follows:

5) "Diikuti beberapa lelaki rimba dari beberapa rombong di dekat sana mereka pun berkumpul di sebuah kawasan sawit yang telah tumbang. Sebuah rawa berlumpur serupa goronggorong terbentuk dari lubang-lubang bekas sawit yang tercerabut. Tanah tepiannya bergambut dengan air yang sangat pekat dan berminyak. Ada sebuah batang sawit besar yang rebah dengan pesona lapuknya ditumbuhi daun-daun paku”. (Rasyid, US)

Data (5) explains that oil palm areas that are no longer operating changes into a muddy swamp with large holes and flooded with oily concentrated water. The area planted with oil palm trees will become a barren area because oil palm is a tree that requires a lot of water during its maintenance. It also requires a lot of fertilizer derived from substances that can damage the soil ecosystem. Therefore, most of the land in the areas which are overgrown with oil palm can no longer be used. According to Keraf (2010), the oil-palm plantation will also give direct damage to the soil from intensive farming because it uses various chemical substances.

\section{Animals}

Two data are showing the problem of animal and environmental destruction. The data are in Dalam Lingkaran Laut (DLL) by Jemmy Piran. It narrates a story of a fisherman named Koli who lives wisely to preserve and harmonize with nature, as well as the sea. He obeys the traditions of his ancestors. The excerpts are explained as follows.

6) "Memang beberapa tahun terakhir ikan berkurang karena penangkapan yang berlebihan, tapi, baginya, itu bukan persoalan karena tangkapannya selalu mencukupi. Terumbu karang rusak karena bom. Ikan-ikan kecil dan besar mati karena diracun potas." (Piran,DLL).

Data (6) describes the environmental problem that occurs in the sea. Catching fish using potassium or fish bombs causes the death of fish and the damage of coral reefs. Keraf (2010) stated that the damage to coral reefs occurred due to the practice of coral fish bombing by coastal residents as well as sedimentation and pollution of waste, coral cleansing, and others. The level of coral reefs could not increase from year to year due to this practice. The main character, Koli, is described as a young man who is firm in holding his ancestral customs about fishing in the sea. The main impact of coral reef damage is the decline in marine biota populations, especially reef fish due to disturbance and habitat loss of coral reefs.

\section{B. The Principles of Environmental Ethics}

The principle of environmental ethics lies in the theory of biocentric and eco-centricity (Keraf, 2010). This principle is motivated by an ecological crisis that is based on anthropocentric perspectives and behavior. After a critical reading of the four short stories, there are three types of environmental ethical principles, (1) compassion for nature bearing, (2) respect for nature bearing, and (3) life in harmony with nature bearing. The following are the principles of environmental ethics included in the 2017 edition of Jawa Pos short stories.

\section{Compassion and Care for Nature Bearing}

There are two data containing compassion and care for nature. In Pertunjukan Hari Ketujuh, Kodrat, as one of the residents of the Mount Bokong valley, cares for the fate of the residents and the preservation of nature in his village. Therefore, he and several other inhabitants of the village go to the presidential palace, hold a demonstration for seven 
days to express their aspirations and to reject the establishment of a cement factory. The data is elaborated as follows.

7) "Kami menolak pendirian pabrik semen di lembah Gunung Bokong, berada di wilayah desa kami," kata Kodrat. (Utomo,PHK).

Kodrat rejects the existence of the cement factory. This is the real attitude showing his concern for the Mount Bokong region. He expresses compassion and care. He also performs an ecological perspective emphasizing the equality of all living things. He believes that they have the right to be protected, cared for, and not hurt (Keraf, 2010). People are required to love and care for nature, and its entire elements, without discrimination and domination.

Other data reveals the affection and care for nature bearing in Nini Rumi.

8) "Di hutan, nikmat sekali untuk bernyanyi. Begitu rasa Nini Rumi. Di antara sela-sela pepohonan dan rumput, mempertemukan sunyi pada dahan dan daun, bertukar irama dengan burung-burung. Berbalas nyanyian dengan angin. Serasa sampai mempertemukan kerinduan dengan yang tak terlihat." (Lesmana,NR).

The above data portrays Nini Rumi as a woman who loves nature. Her affection for nature is reflected in her songs to nature. Nini Rumi sings together with the forest, with the breeze of the wind and the sway of the leaves. Keraf (2010) adds that as humans increasingly love and care for nature, they develop into mature individuals with a strong connection to nature. Nature is alive not only in a physical sense but also in a mental and spiritual sense. In the perspective of Deep Ecology, humans increasingly grow along with nature. They grow into a calm and peaceful character and personality.

\section{Respect to Nature Bearing}

In this principle, four data are found in Jemey Piran's Dalam Lingkaran Laut (DLL). This principle is based on the theory that the ecological community is a moral community and each member of the human community does not have a moral obligation to respect each other (Keraf, 2010). Koli in data (9) is described as a fisherman who obeys the rules of nature. He is obedient to the advice of his ancestors. This makes nature stay sustainable with mutual respect. He respects nature and guards to avoid destruction. The data excerpts are as follows.

9) “Ketika orang-orang menggunakan perahu mesin, ketinting, pukat harimau, pukat jepang, pergi ke tempat yang jauh untuk mendapat ikan yang banyak, ia justru hanya menggunakan dayung dan sampan kayunya yang sudah agak lapuk. Ia meninggalkan pesisir, cukup mendayung ke tengah laut, lalu menurunkan pukatnya." (Piran,DLL).

Respecting nature is a basic principle for humans as a part of the universe. Every member of the social community has an obligation to respect a harmonious life. Every living thing must respect other living things in the ecological community. Nature has the right to be respected, not only because human life depends on nature, but the main point is the fact that humans are part of nature.

10) "Saat orang-orang mengandalkan ilmu pengetahuan untuk menangkap ikan, ia masih menggunakan cara lama. Mengeruk sedikit bala, membungkusnya dalam kapas dan meletakkan kapas itu di sudut pesisir setelah merapalkan mantra, di antara bakau, dan satunya lagi ia larungkan ke laut." (Piran,DLL)

It is also explained that the procedure for fishing is without using tools that could damage the marine ecosystem. The best method is the traditional one. Many fishermen have left the tradition that Koli practices, which is praying to God. To him, praying is the key, so that the Almighty God gives generosity upon him. Praying is an attitude or ethics in respecting nature and ancestors. Koli believes in the teachings of his ancestors, and he believes in mutual relations. He believes that we have to return to nature for what we have taken from it. The data justifying this are reinforced in the following story.

11) "Karena seperti yang diwasiatkan oleh tetua, segala yang berkeriap dalam laut punya tuan maka untuk mengambil hasil laut setidaknya ada sesuatu yang harus diberikan sebagai ganti. Begitu juga dengan semua binatang yang berkaki dan melata di darat juga mempunyai tuan. Juga tidak harus melupakan Sang Pemilik Segala: Tuhan."(Piran,DLL).

In data $(9,10,11)$, the attitude of respecting nature is very clear. Humans have an obligation to respect living things as this is a morally correct and based on an eco-centric and biocentric perspective. Keraf (2010) concludes that some positive attitudes for nature are manifested in 1) the ability to respect nature, 2) awareness that nature has values in itself, 3) awareness that nature has the right to be respected, 4) awareness that nature has integrity, and 5) appreciation for nature in terms of its existence, living, growing, and natural development.

\section{Living in harmony with nature bearing}

Three data containing the principle of living in harmony with nature are found. The first one is reflected in Nini Rumi (NR).

12) "Sambil memungut ranting kering, mengumpulkan kayu bakar, nyanyiannya tak pernah usai, selalu saja mendadak ada suara waditra dalam dadanya. Suara gendang, gong, dan kenong muncul merengkuhnya. Serasa tumbuh dari batu, dari daun, dari burung. Tumbuh dari gunung." (Lesmana,NR).

This principle emphasizes that the value or quality of a good life is not based on wealth, facilities, or material standards (Keraf, 2010). Nini Rumi represents someone who loves nature and live a good life in the accompany of nature. She positions herself like other creatures, thus she could respect the living plants and organisms in the forest.

The next data is obtained from Dalam Lingkaran Laut. 
13) "Betapa bahagia ia ketika melihat warga yang membeli hasil tangkapannya. Ia selalu melebihkan beberapa ekor ikan. Kadang ia membagikan secar gratis kepada warga.kadang memang harus diberikan secara gratis agar rezeki terus melimpah, pikirnya. Begitulah kerja alam.” (Piran,DLL).

14) "Betapa Koli meyakinkan warga bahwa menangkap ikan bukan hanya soal bagaimana mengusai ilmu pengetahuan, menggunakan alat-alat canggih, tapi harus juga menggunakan pengetahuan yang diturunkan dari nenek moyang, warga tetap tidak percaya." (Piran,DLL)

15) “Wasiat itulah yang sampai sekarang masih ia pegang dengan teguh. Hanya ada satu larangan: tidak boleh mengambil sesuatu secara berlebihan. Di tengah laut, Koli bisa mengenang banyak hal tentang alam yang selalu berbaik padanya. Ia merasa telah menjaga keseimbangan alam dengan baik." (Piran,DLL).

From the data $(13,14,15)$, Koli exemplifies the ways to live in harmony with nature. The basic principle is that humans must recognize themselves as a part of nature, so they could utilize nature sufficiently. There is a natural law that must be obeyed, which is to live by utilizing nature in moderation. It means that overexploitation to nature that causes harm should be stopped. Keraf (2018) elaborates that communal movement and commitment are needed to change humans' lifestyles. We have to accept that environmental damage is caused by human behavior. It happens due to overconsumption and exploitation of humans to nature. The way to encounter the damage is by applying a positive moral principle of simple living and befriend with nature and ecosystem life.

\section{CONCLUSION}

Based on the investigation of the four short stories, some environmental problems found in the stories are related to soil pollution, forest, and animal issues. Meanwhile, the principles of environmental ethics are affection to nature, the responsibility to nature, life in harmony with nature, and respect for nature bearings. During the period of 2017, very few authors raised the theme of the environment as environmental themes have not become a major issue for many authors. Environmental problems should be the main concern for all parties, not only writers and readers. It is hoped that the short stories of newspaper literature will not only be an entertaining reading but a reflection and a reprimand for all of us.

\section{REFERENCES}

Bandel, K. (2006). "Sastra Koran di Indonesia” dalam Sastra, Perempuan, \& Seks. Yogyakarta: Jalasutra.

Christinawati. (2018). Ecological Literacy to Build Harmony: A Critical Study on Environmental Poems. Advances in Social Science, Education and Humanities Research (ASSEHR), volume 188 UNNES International Conference on English Language Teaching, Literature, and Translation (ELTLT 2018). Published by Atlantis Press.

Dewi, N. (2015). Manusia dan Lingkungan dalam Cerpen Indonesia Kontemporer: Analisis Ekokritik Cerpen Pilihan Kompas. Litera, Volume 14, Nomor 2, Oktober 2015.1

ndraswara, S. (2016). Metodologi Penelitian Ekologi Sastra Konsep, Langkah, dan Penerapan. Yogyakarta: CAPS (Center For Academic Publishing Service).

Garrard, G. (2004). Ecocriticism. New York: Routledge.

Glotfelty, C., \& Fromm, H. (eds). (1996). The Ecocriticsm Reader Landmark in Literary Ecology. Georgia: Universitas of Georgea Press.

Hunga, A. I. R \& Candraningrum, D [Ed.]. (2016). Ekofeminisme IV: Tanah, Air, dan Rahim Rumah. $\quad$ Yogyakarta: Parahita Press.

Juliasih. K. (2012). Manusia dan Lingkungan dalam Novel Life In The Iron Mills Karya Rebecca Hardings Davis. LITERA, Volume 11, Nomor 1, April 2012

Keraf, S. A. (2010). Etika Lingkungan. Jakarta: Kompas.

Keraf, S.A. (2010). Krisis dan Bencana Lingkungan Hidup Global. Yogyakarta: Penerbit Kanisisus.

Lesmana, T. (2017). Nini Rumi. Jawa Pos. (Koran Jawa Pos edisi 7 Mei 2017).

Nadjmuddin, R. (2005). Membangun Lingkungan Hidup yang Harmonis \& Berperadaban. Jakarta: Grafindo Khazanah Ilmu.

Piran, J. (2017). Dalam Lingkaran Laut.. Jawa Pos. (Koran Jawa Pos edisi 3 September 2017).

Rasyid, D. (2017). Ular Sawit. Jawa Pos. (Koran Jawa Pos edisi 22 Oktober 2017).Sudikan, S. Y. (2016). Ekologi Sastra. Lamongan: CV. Pustaka Ilalang Group.

Utomo, S.P. (2017). Pertunjukkan Hari Ketujuh. Jawa Pos. (Koran Jawa Pos edisi 22 Januari 2017).

Wiyatmi. (2015). Kritik Sastra Indonesia: Feminisme, Ekokritisme dan New Historisme. $\quad$ Yogyakarta: Interlude. 